\title{
MODEL PENDIDIKAN PESANTREN BERBASIS WIRAUSAHA DAN IMPLIKASINYA TERHADAP KEMANDIRIAN SANTRI
}

\author{
Nimim Ali \\ Universitas Muhammadiyah Luwuk \\ Email:nimim03ali@gmail.com
}

\begin{tabular}{|c|c|}
\hline \multirow[t]{2}{*}{ Jou } & \\
\hline & Abstract. \\
\hline p-ISSN : 2579-5082 & Penelitian ini bertujuan untuk: Mengetahui bagaimana \\
\hline e-ISSN : $2598-2818$ & model dan implementasi program pendidikan Pesantren \\
\hline DOI : http:// & berbasis wirausaha di Pesantren Salafiyah Syafi'iyah \\
\hline 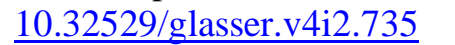 & Randangan Gorontalo. \\
\hline Volume : 4 & Jenis penelitian kualitatif \\
\hline Nomor : 2 & deskriptif.Pendekatan yang digunakan adalah pendekatan \\
\hline Month : 2020 & Partisipasi Action Resarc (PAR).Metode pengumpulan \\
\hline Issue : Oktober & data dalam penelitian ini pula dalam bentuk observasi, \\
\hline & $\begin{array}{l}\text { wawancara dan dokumentasi.Hasil penelitian } \\
\text { menunjukkan bahwa: Implementasi program pendidikan }\end{array}$ \\
\hline & Pesantren berbasis wirausaha di Pesantren Salafiyah \\
\hline & $\begin{array}{l}\text { Syafi'iyah meliputi keterampilan dibidang pertanian, } \\
\text { peternakan pertukangan (mebel) }\end{array}$ \\
\hline & $\begin{array}{l}\text { konfeksi. Dalam pelaksanaannya, para santri } \\
\text { mempraktekan secara langsung di lapangan.Sedangkan }\end{array}$ \\
\hline & lahan dan segala fasilitas untuk mengasah dan melatih \\
\hline & keterampilan tersebut telah disediakan oleh Pondok \\
\hline & $\begin{array}{l}\text { Pesantren.Model pendidikan Pesantren berbasis wirausaha } \\
\text { vang diterapkan di Pesantren Salafivah Svafi'ivah vaitu: }\end{array}$ \\
\hline & pertama, model integratif. Dalam model ini, Pesantren \\
\hline & (klasikal) dengan pendidikan umum melalui metode \\
\hline & pembelajaran modern.Kedua, model produktif. Dapat \\
\hline & dibutuhkan Pondok Pesantren memiliki kemampuan \\
\hline & berpikir kreatif dan inovatif serta keterampilan (skill) \\
\hline & dalam berwirausaha akan sangat diperlukan demi \\
\hline & $\begin{array}{l}\text { mencapai suatu tujuan serta penanaman spirit dan jiwa } \\
\text { wirausaha bagi para peserta didiknya. }\end{array}$ \\
\hline
\end{tabular}

Keywords: Model, Implikasi, Santri 
Secara kelembagaan, sebenarnya

\section{A. PENDAHULUAN}

Memiliki peran sebagai lembaga sosial yang mempunyai pola dan karakteristik pengelolaan yang khas, Pondok Pesantren dengan berbagai harapan dan predikat yang dilekatkan kepadanya, sesungguhnya berujung pada tiga fungsi utama yang senantiasa diemban-nya, yaitu : Sebagai pusat pengkaderan pemikir-pemikir agama(centre of exellence)Sebagai lembaga yang mencetak sumber daya manusia (human resource), Sebagai lembaga yang mempunyai kekuatan dalam melakukan pemberdayaan pada masyarakat (agent of development).(Suhartini, 2005, hal.233)

Selain ketiga fungsi tersebut, Pesantren juga dipahami sebagai bagian yang terlibat dalam proses perubahan sosial (social of change) di tengah perubahan yang terjadi. Pada batas tertentu Pesantren tergolong di antara lembaga pendidikan keagamaan swasta yang leading, dalam arti berhasil merintis dan menunjukkan keberdayaan baik dalam hal kemandirian penyelenggaraan maupun pendanaan (self financing). Selain menjalankan tugas utamanya sebagai kegiatan pendidikan Islam yang bertujuan regenerasi ulama, Pesantren telah menjadi pusat kegiatan pendidikan yang konsisten dan relatif berhasil menanamkan semangat kemandirian, kewiraswastaan, semangat berdikari yang tidak menggantungkan diri kepada orang lain. (Habib Thoha, 1996 hal. 52)
Pesantren telah memberikan contoh riil (bi alhal) dengan mengaktualisasikan semangat kemandirian melalui usaha-usaha yang konkret dengan didirikannya beberapa unit usaha ekonomi mandiri Pesantren.Melalui usaha kemandirian tersebut, dapat dilihat bahwa Pesantren mempunyai andil yang cukup besar untuk menggalakkan wirausaha.Karena di lingkungan Pesantren, para santri dididik untuk menjadi manusia yang bersikap mandiri dan berjiwa wirausaha. (Wahjoetomo, 1997, hal. 95)

Pondok Pesantren semestinya melestarikan sejarah syiar Islam dengan mempersiapkan para santrinya, tidak hanya menjadi santri yang handal dari aspek moralitas, tetapi juga menjadi pengusaha yang handal dan Islami. (Suryadharma Ali, 2013, hal. 13). Salah satu cara yang perlu dilakukan adalah memberikan bekal wirausaha dan keterampilan usaha sejak dini kepada para santri.

Kewirausahaan merupakan kemampuan dalam menciptakan sesuatu yang baru dan berbeda. Menurut Kasmir, Mengapa perlu berwirausaha? Agar mampu menatap masa depan yang lebih baik. Dengan berwirausaha diharapkan seseorang mampu mandiri, bekerja keras dan membuka lapangan kerja bagi orang lain.

Secara kelembagaan, sebenarnya Pesantren telah memberikan contoh riil (bi alhal) dengan mengaktualisasikan semangat kemandirian melalui usaha-usaha yang 
konkret dengan didirikannya beberapa unit usaha ekonomi mandiri Pesantren. Melalui usaha kemandirian tersebut, dapat dilihat bahwa Pesantren Salafiyah Syafi'iyah Randangan Gorontalo mempunyai andil yang cukup besar untuk menggalakkan wirausaha. Karena di lingkungan Pesantren, para santri dididik untuk menjadi manusia yang bersikap mandiri dan berjiwa wirausaha. Pesantren giat berusaha dan bekerja secara independen tanpa menggantungkan nasib pada orang lain atau lembaga pemerintah swasta. Jadi, pengembangan berbagai usaha ekonomi di Pesantren Salafiyah Syafi'iyah Randangan Gorontalo dimaksudkan untuk memperkuat pendanaan Pesantren, latihan bagi para santri, dan pemberdayaan ekonomi masyarakat.

Artinya, tidak bisa dipungkiri bahwa, keberadaan Pondok Pesantren menjadi bagian dari sistem kehidupan umat Islam sekaligus penyangga budaya masyarakat Indonesia terutama pada masa penjajahan sehingga Pondok Pesantren tidak hanya dituntut untuk mengurusi pendidikan agama atau pembelajaran agama Islam, namun juga menanamkan nilai-nilai kewirausahaan dimasyarakat.

Belajar agama di Pesantren itu sudah biasa. Namun belajar wirausaha di Pesantren tentu berbeda. Pasalnya Pesantren selama ini identik dengan ilmu agama yang berkaitan dengan pembekalan mental (ukhrawi), sementara wirausaha terkesan pada pembekalan keterampilan (Skill) yang bersifat duniawi. Bukan suatu hal yang tidak mungkin bahwa kedua hal tersebut terkesan berseberangan dan tidak bisa dipadukan. Keduanya sangat mungkin terpadu bahkan saling menguatkan satu sama lain. Berdasarkan uraian di atas, maka penelitian ini bertujuan Untuk mengetahui model dan implementasi program pendidikan Pesantren berbasis wirausaha di Pesantren Salafiyah Syafi'iyah Randangan Gorontalo.

\section{B. METODE PENELITIAN}

\section{Pendekatan Penelitian}

Pendekatan ini menggunakan pendekatan Partisipasi Action Resarc (PAR) yakni suatu bentuk pendekatan untuk mengetahui dan menggambarkan model Gorontalo. Jadi objek penelitian melalui pendekatan PAR adalah keterlibatan Ketua Yayasan, manajer bidang usaha Pesantren, guru-guru dan santri-santri.

\section{Jenis Penelitian}

Jenis penelitian kualitatif dengan metode deskriptif yang berupaya mengetahui model dan implementasi program pendidikan Pesantren berbasis wirausaha di Pesantren Salafiyah Syafi'iyah Randangan Gorontalo.

\section{Lokasi Penelitian}

Lokasi penelitian ini dilakukan di Pondok Pesantren Salafiyah Syafi'iyah ,terletak pada radius 3,5 kilometer dari jalan Trans Sulawesi, dan kurang lebih ( \pm ) 200 kilometer dari ibu kota Provinsi Gorontalo. Tepatnya di Desa Banuroja Kecamatan Randangan Kabupaten Pohuwato. Penelitian dilakukan sejak bulan Maret 2017 hingga bulan Juni 2017 


\section{Sumber Data}

Sumber data dalam penelitian ini terdiri dari data primer dan data sekunder.

1. Data Primer merupakan data utama yang berupa kata-kata dan tindakan orang-orang yang diamati dan diwawancarai. (Lexy J. Moleong, 2005, hal. 156). Dalam hal ini adalah kepala sekolah, guru , dan beberapa santri.

2. Data Sekunder adalah data yang diperoleh dari berbagai dokumen, tulisan dan arsiparsip yang berkaitang dengan objek penelitian.

\section{Prosedur Pengumpulan Data}

Adapun prosedur pengumpulan data pada penelitian ini adalah:

1. Observasi. Yaitu peneliti melakukan pengamatan langsung di Pondok Pesantren Salafiyah Syafi'iyah.

2. Wawancara. Yaitu peneliti mendapatkan informasi dengan cara bertanya langsung kepada responden.

3. Dokumentasi. Digunakan untuk mendukung instrument observasi dan wawancara dengan menunjukkan data di lapangan yang sudah ada.

\section{HASIL DAN PEMBAHASAN}

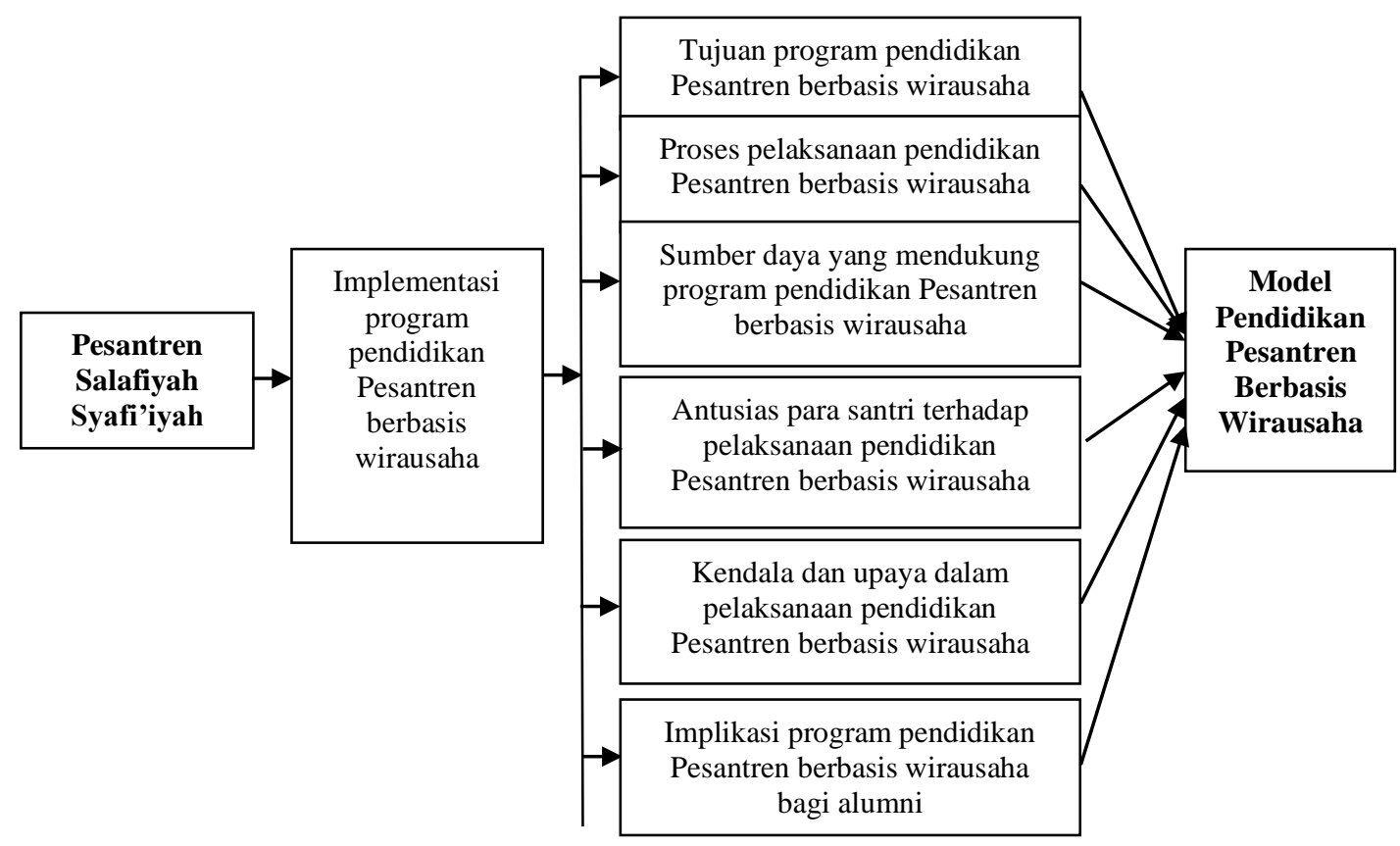

Analisis terhadap model pendidikan Pesantren berbasis wirausaha yang telah berjalan dalam praktek pendidikan di Pesantren Salafiyah Syafi'iyah, dapat diklasifikasikan berdasarkan dua unsur utama yaitu model integratif dan model
produktif.Kedua unsur tersebut merupakan rangkaian komponen pendidikan dan pengajaran yang saling berkaitan, serta saling menunjang untuk pencapaian tujuan yang telah ditetapkan dalam pendidikan berbasis wirausaha. 


\section{Model Integratif}

Salah satu komponen utama dalam proses pembelajaran adalah formulasi kurikulum, karena kurikulum merupakan unsur utama dalam penyelenggaraan pendidikan. Sebagai suatu sistem,kurikulum memuat tujuan, isi/ metode, dan evaluasi.

Dewasa ini, karakteristik kurikulum yang ada di Pondok Pesantren Salafiyah Syafi'iyah telah diadaptasikan dengan kurikulum pendidikan Islam yang disponsori oleh Departemen Agama melalui sekolah formal (Madrasah).Sedangkan kurikulum khusus Pesantren dialokasikan dalam muatan lokal atau diterapkan melalui kebijakan sendiri yaitu ekstrakurikuler.

Pengembangan kurikulum muatan lokal ini, oleh Pesantren Salafiyah Syafi'iyah ditandai dengan peralihan dari sistem pendidikan tradisional ke pendidikan modern yang berbasis wirausaha.Dalam rangka menghadapi tantangan globalisasi serta kemajuan tekhnologi yang begitu pesat, maka Pesantren Salafiyah Syafi'iyah menerapkan pendidikan berbasis wirausaha.Tujuan yang ingin dicapai yaitu untuk mendanai segala kebutuhan Pesantren baik dari pengembangan fasilitas sarana dan prasarana, juga kebutuhan lainnya seperti honor para guru abdi dan guru kontrak yang dibiayai secara mandiri oleh Pesantren.

Selain itu, tujuan lain dilaksanakannya pendidikan berbasis wirausaha ini adalah untuk membekali para santri yang mengenyam pendidikan di Pesantren Salafiyah Syafi'iyah agar lebih berjiwa kreatif, inovatif, mandiri dan memiliki keterampilan hidup (life skill). Sehingga mereka tidak hanya menguasai ilmu agama saja, tetapi juga terampil dalam ilmu pengetahuan umum seperti pendidikan wirausaha yang berguna bagi kehidupan pribadi, keluarga dan masyarakat di sekitar mereka.

\section{Model Produktif}

Kegiatan wirausaha yang dijalankan sejak tahun 2006 oleh Pesantren Salafiyah Syafi'iyah telah meliputi berbagai bidang usaha yang dapat penulis deskripsikan sebagai berikut :

\section{1) Pertanian}

Praktek yang dijalankan dibidang pertanian ini adalah: pertama, menanam jagung. Setiap tahun, Pesantren melakukan panen sebanyak 2 kali. Biasanya hasil dari setiap panen (1 kali) mencapai \pm 3 ton.Hasil panen tersebut, sebagian langsung dijual kepada tengkulak dan sisanya diproduksi menjadi Emping Jagung dan Baalo Binthe.

Kedua, menanam padi.Lahan yang diolah untuk menanam padi ini adalah lahan milik masyarakat yang dijalankan dengan sistem bagi hasil.Hasil panen padi ini tidaklah dijual, namun dikonsumsi secara pribadi oleh Pesantren.

\section{2) Peternakan}

Ternak sapi adalah merupakan salah satu usaha yang sedang dikembangkan di Pesantren Salafiyah Syafi'iyah dibidang peternakan.Penggemukan dan pembuatan (pengolahan) pupuk dari hasil kotoran sapi 
adalah merupakan bagian dari pengembangan ternak sapi ini.

Saat ini Pesantren Salafiyah Syafi'iyah memiliki 19 ekor sapi yang dipelihara oleh kelompok "Pemuda Mandiri".Setiap tahun menjelang hari raya Idul Adha, sapi-sapi ini dibeli oleh masyarakat dan dijadikan sebagai hewan qurban.Adapun keuntungan yang dihasilkan dari penjualan sapi tersebut berkisar 3-5 juta/ ekor.

Selain ternak sapi di atas, budidaya ikan lele juga merupakan usaha komersial yang mulai dikembangkan.Saat ini Pesantren memiliki tambak ikan lele, tetapi hasil panennya masih dikonsumsi secara pribadi oleh Pesantren. Berdasarkan wawancara penulis dengan informan bahwa terkait budidaya ikan lele ini nantinya akan lebih diperluas sampai ke masyarakat yang ada di wilayah Kecamatan Randangan.

3) Pertukangan (Mebel)

Usaha mebel di Pesantren Salafiyah Syafi'iyah lebih banyak menerima pesanan seperti meja dan kursi belajar, lemari berkas dan meja bulat (besar).Biasanya setiap tahun Pesantren menerima 5 pesanan dalam bentuk paket (meja dan kursi belajar, lemari berkas) yang dipesan oleh sekolah-sekolah atau instansi-instansi yang ada di wilayah Kabupaten Pohuwato.Adapun harga bagi pembelian kursi dan meja belajar yaitu Rp. 400.000/ unit, sedangkan lemari berkas dijual dengan harga Rp. 2.500 .000 dan meja bulat (besar) Rp. 3.500.000.

4) Konfeksi
Pada tahun ajaran baru, Pesantren Salafiyah Syafi'iyah banyak menerima pesanan paket seragam siswa dan siswi yang dipesan oleh sekolah-sekolah yang ada di wilayah Kabupaten Pohuwato.Biasanya pesanan paket seragam ini berkisar 100-200 paket yang dijual dengan harga Rp. 175.000/ paket.

Dalam perkembangannya, unit usaha yang dikembangkan oleh Pesantren Salafiyah Syafi'iyah digabungkan dalam satu wadah, yaitu Koperasi Pondok Pesantren (Kopontren).Secara resmi, kopontren ini dibuka dan didaftarkan ke Departemen Koperasi dengan Nomor:38/BH/KWK.18/X/1996 (bulan Oktober 1996).

\section{PENUTUP}

Kesimpulan.

Berdasarkan uraian pada pembahasan sebelumnya maka penulis mengemukakan kesimpulan bahwa

1. Implementasi program pendidikan Pesantren berbasis wirausaha di Pesantren Salafiyah Syafi'iyah meliputi keterampilan dibidang pertanian, peternakan, pertukangan (mebel), perkebunan dan konfeksi.Pendidikan berbasis wirausaha ini bertujuan untuk meningkatkan kesejahteraan para guru serta pengembangan fasilitas sarana dan prasarana yang menunjang proses pembelajaran di Pesantren. Selain itu, untuk menumbuhkan semangat dan jiwa 
wirausaha bagi para santri sehingga ia mampu hidup tanpa bergantung kepada orang lain (mandiri) dan tidak menjadi beban bagi siapapun. Bahkan lebih dari itu kehadirannya justru membawa manfaat bagi banyak orang. Dalam pelaksanaannya, para santri mempraktekan secara langsung di lapangan. Sedangkan lahan dan segala fasilitas untuk mengasah dan melatih keterampilan tersebut telah disediakan oleh Pondok Pesantren.

Model pendidikan Pesantren berbasis wirausaha yang diterapkan di Pesantren Salafiyah Syafi'iyah yaitu: pertama, model integratif. Dalam model ini, Pesantren mengintegrasikan antara sistem pendidikan tradisional (klasikal) dengan pendidikan umum melalui metode pembelajaran modern. Kedua, model produktif. Dalam model ini, ada tiga hal yang ingin dicapai oleh Pesantren Salafiyah Syafi'iyah di antaranya, yaitu menjadikan para santri kompeten dan produktif secara spiritual, kompeten dan produktif secara sosial, kompeten dan produktif secara ekonomi.

\section{Saran}

Adapun beberapa hal-hal yang menjadi rekomendasi penulis yaitu:

1. Pendidikan Pesantren berbasis wirausaha merupakan salah satu upaya dalam menghadapi perkembangan dan tantangan zaman yang kian pesat. Kedepan bukan hanya penguasaan tekhnologi yang dibutuhkan, tetapi jugakemampuan berpikir kreatif dan inovatif serta keterampilan (skill)dalam berwirausaha akan sangat diperlukan demi mencapai suatu tujuan. Oleh karena itu, penulis merekomendasikan kepada lembagalembaga pendidikan termasuk Pesantren harus mempersiapkan bekal pengetahuan serta penanaman spirit dan jiwa wirausaha bagi para peserta didiknya.

Dalam penelitian ini, penulis hanya meneliti tentang model pendidikan Pesantren berbasis wirausahadi Pesantren Salafiyah Syafi'iyahRandangan Gorontalo. Oleh karena itu, penulis merekomendasikan bagi lainnya untuk melakukan penelitian lainnya yang dianggap urgen untuk dilakukan penelitian serta lebih mendalam lagi hasil yang dipaparkan, sebagai bentuk keragaman penelitian dan menambah khasanah keilmuan khususnya dalam bidang pendidikan kewirausahaan.

\section{E. REFERENSI}

Agustino, Leo. Dasar-Dasar Kebijakan Publik. (Bandung: Alfabeta, 2008).

Ali, Suryadharma. Paradigma Pesantren Memperluas Horizon Kajian dan Aksi. (Malang: UIN Maliki Press, 2013).

Ahmad Faozan, Pondok Pesantren dan Pemberdayaan Ekonomi. Jurnal Ibda', Vol. 4, No 1 Tahun 2006. h. 12

Alma, Buchari.Kewirausahaan Untuk Mahasiswa dan Umum. (Bandung:

Alfabeta, 2008)

Amalia, Rizki Brida.Implementasi Pembelajaran Kewirausahaan Melalui Praktek Prakarya di SMK PGRI 3 Malang, Skripsi.( UIN Maulana Malik Ibrahim Malang: t.tp, 2016). h. 58

Chusnul Chotimah, Pendidikan Kewirausahaandi Pondok Pesantren Sidogiri Pasuruan, Jurnal Penelitian 
Sosial Keagamaan Vol. 8, Nomor. 1, Juni 2013

\section{Departemen Koperasi dengan Nomor:38/BH/KWK.18/X/1996 (bulan Oktober 1996)}

Moleong, Lexy J., Metodologi Penelitian Kualitatif, Bandung: Remaja Rosdakarya, 2005.

Mahmud Ali Zein, Model-Model Perkembangan Pondok Pesantren: Pengalaman Pondok Pesantren Sidogiri Pasuruan. dalam A. Halim, et. al. (ed), Manajemen Pesantren. (Yogyakarta: Pustaka Pesantren, 2005). h. 305-307

Kasmir, Kewirausahaan-Edisi Revisi, Cet. Ke-7. (Jakarta: Raja Grafindo).
Suhartini, Problem Kelembagaan Pengembangan Ekonomi Pondok Pesantren, dalam A. Halim et. al. Manajemen Pesantren. (Yogyakarta: Pustaka Pesantren, 2005).

Thoha, Habib. Kapita Selekta Pendidikan Islam.(Yogyakarta: Pustaka Pelajar, 1996).

Usman, Husaini dan Nuryadin Eko Raharjo, Model Pendidikan Karakter Entrepreneuship di Sekolah Menengah Kejuruan.Jurnal Pendidikan Teknologi dan kejuruan, Vol. 21 Nomor 2, Oktober 2012

Wahjoetomo, Perguruan Tinggi Pesantren Pendidikan Alternatif Masa Depan. (Jakarta: Gema Insani Press, 1997). 